\title{
Biopolitics of COVID-19: Capitalist Continuities and Democratic Openings
}

https://doi.org/10.51897/interalia/OAGM9733

\author{
Karsten Schubert \\ Albert-Ludwigs-University of Freiburg \\ ORCID: 0000-0002-6322-3370
}

\begin{abstract}
"Biopolitics" has become a popular concept for interpreting the COVID-19 pandemic, yet the term is often used vaguely, as a buzzword, and therefore loses its specificity and relevance. This article systematically explains what the biopolitical lens offers for analyzing and normatively criticizing the politics of the coronavirus. I argue that biopolitics are politics of differentiated vulnerability that are intrinsic to capitalist modernity. The situation resulting from the COVID-19 pandemic is, therefore, less of a state of exception than it might appear; COVID-19 is a continuation and intensification of the capitalist biopolitics of differentiated vulnerability. In order to critically evaluate this situation, the article proposes the concept of "democratic biopolitics" and shows how it can be used, among others, for a queer critique of the differentiated vulnerabilities that are produced by the coronavirus and its capitalist governance. In contrast to widespread interpretations of democratic biopolitics that focus on collective care in communities, this article highlights the role of the state and of the redistribution of political power and economic resources as key for biopolitical democratization.
\end{abstract}

Keywords: biopolitics, democratic biopolitics, COVID-19, coronavirus, capitalism, queer politics, redistribution

We live in very Foucauldian times, as the many articles and essays published on biopolitics and COVID-19 suggest. However, the term biopolitics is often used vaguely or as a buzzword, losing its specificity and relevance. Therefore, in this piece, I first systematically explain what the biopolitical lens offers for analyzing the politics of COVID-19, and then show how the biopolitical vocabulary could be further developed towards normative concepts that would effectively evaluate the biopolitics of the coronavirus. The biopolitical lens elucidates two points: that biopolitics are politics of differentiated vulnerability that are intrinsic to capitalist modernity, and that the coronavirus situation is therefore significantly less of a state of exception than it may seem to be. Rather, COVID-19 is a continuation and intensification of the capitalist biopolitics of differentiated vulnerability. In order to critically evaluate this situation, I propose the concept of "democratic biopolitics" and show how it can be used for a queer critique of the differentiated vulnerabilities that are produced by the coronavirus and its capitalist governance. As opposed to other interpretations of democratic biopolitics, I highlight the role of the state instead of the collective care of the community (Sotiris, 2020; Schaffar, 2020). Populist biopolitics, I argue, blend out such differentiated vulnerabilities by constructing an absolutist biopolitical regime in the name of the people, putting forward either health or individual freedom as unquestionable values that must be protected at all costs. 


\section{Biopolitics and Capitalist Modernity}

The contemporary conception of "biopolitics" was coined by Michel Foucault. Foucault was concerned with power, that is, with how people are governed, which techniques are used for government, and how these relate to knowledge and science. Biopolitics, he argued, is a certain form of power that emerged in the late 18th and the 19th century, and which still shapes our present. Biopolitics means, according to Foucault, that governments have taken life, or more precisely the population and its health, birth rates, death rates, etc., as their new object. New technologies of power, and new kinds of knowledges, such as medical and statistical knowledge, were developed in order to influence the population. Surveillance and the control of sexuality, as well as the emerging systems of insurance and welfare, are central. Foucault describes this as a historical rupture: Never before has politics been in charge of overseeing biological processes so closely and in such scientific and systematic ways.

Foucault develops the concept of "biopolitics" in The History of Sexuality I (1978) and the Governmentality Lectures $(2007 ; 2010)$. In the latter Foucault argues that modern governmentality operates through a specific kind of power over life, which rules both the individual and the collective. On the individual level, biopolitics operates through disciplinary power, which Foucault analyzed in his earlier Discipline and Punish ([1975] 1977). On the collective level, biopolitics consists of the regulation of the population through scientific knowledge, such as demography and statistics. Today, biopolitics is based not only on discipline but also on control as a mode of power, that relies on contemporary digital technologies and neoliberal decentralization, as Deleuze (1992) and contemporary governmentality studies show (Dean, 1999). Moreover, through new medical technology, biopolitical governance and ethics have become significantly more complex and nuanced than in the $19^{\text {th }}$ century, when it centered on the reproduction of the work force and military force. The fact that contemporary biopolitics include possibilities of medical enhancement on a molecular level, such as pre-implementation genetic diagnostics and hormone therapies for trans people, calls for biopolitical ethics and citizenship, especially given their capitalist organization (Preciado, 2013; Rose, 2007). However, these developments merely reinforce the Foucauldian argument that modernity itself is biopolitical.

I would like to emphasize that the concept of biopolitics can provide a more precise analysis of capitalism than Marxism alone may accomplish. This is important because traditionally, Foucault's theory and Marxism are seen as fundamentally contradictory since Foucault often criticized the Marxism of his day. However, Foucault's critique of Marxism should be viewed as an internal critique among fellow critical social theorists rather than as a fundamental critique. Discipline and Punish is a refined analysis of the modern disciplinary power that makes capitalist industrialism possible, and biopolitics is Foucault's further development of the analysis of modern governmentality. Capitalist mass production is based on complex biopolitics, as these ensure the reproduction and consumption required for ongoing capitalist production and exploitation. Marxist feminists have shown that the exploitation of reproduction is the foundation for modern sexism and bourgeois patriarchy (Federici, 
2014) and Foucault's concept of biopolitics should be read as an additional analysis of such exploitation as rooted in modern power techniques. In sum, we cannot understand capitalism without biopolitics.

Foucault's use of the concept is descriptive, that is, analytical and explanatory, and at the same time normative and critical: he describes the grip biopolitics have on individuals through technologies of power in a way that makes manifest the repression at work in these biopolitical processes. Not only through targeted action to discipline, control, and normalize individuals, but also by "letting die" those who are less relevant in biopolitical considerations. Capitalist accumulation is based on exploitting the workforce and thereby putting workers at risk while ensuring general reproduction. Biopolitics can explain how the "original exploitation" (Marx, 1991: 641-85; Harvey, 2004) of capitalism is not original at all, but an ongoing mode of letting some die while making others live and protecting them. Allowing such violent exploitation by letting some people die, through forcing them to work to death for others, points to the inherent connection between capitalism and racism, as the genesis of capitalism is based on postcolonial exploitation and slavery (Robinson, 2000). According to Foucault (2003: 254ff.), biopolitics is fundamentally intertwined with racism: as soon as the population and its health and hygiene became a policy issue, distinctions were not only made between classes, but also between "races" among national and ethnic lines, and more precisely, between worthy and unworthy lives. Accordingly, Foucault interprets the Third Reich and the Holocaust as radicalizations of this form of power that shapes all of modernity (Foucault, 2003: 259f.).

Thus, biopolitics is fundamentally about unequal treatment, which is inherent to modern capitalism and based on exploitation, sexism, and racism: Biopolitics means making distinctions, exposing some to more risk than others, and offering some more protection than others. Daniele Lorenzini has therefore described biopolitics as a politics of "differential vulnerability" (Lorenzini, 2021)'. Biopolitics has always been about protecting some and exposing others to vulnerability that can, in the most extreme cases, result in death. Examples for this differentiated vulnerability in the current COVID-19 situation are plentiful: think of different working conditions between the home office class and lowincome workers in the meat and plant picking industries that saw massive coronavirus outbreaks in Germany, for example, or the situation of refugees in camps. Another important example of differentiated vulnerability has been provided by the heteronormative regulations that allow easing the strict contact regulations only for heteronormative lifeforms, and not for queer relations. For example, in Germany, contact restrictions were eased during Christmas in a way that privileged heteronormative families and excluded queer sociality (Schubert, 2020).

\footnotetext{
${ }^{1}$ I use the term "differentiated" instead of "differential" vulnerability to indicate that differences are actively produced through biopolitics. The term "differential vulnerability" is also used in medical literature, where it risks essentializing social differences by ignoring their biopolitical production.
} 


\section{Is COVID-19 a State of Exception?}

There has been a lot of talk about the coronavirus situation as exceptional, that is, as a "state of exception." Of course, the situation is exceptional because the state intervenes differently, with restrictions in areas of life that are normally much less regulated. However, I refrain from saying that it intervenes more extensively because I believe we are often caught in a liberal mode of thinking, which does not allow us to see to what degree our routine way of life is thoroughly regulated by politics. For example, a "free" and "unregulated" market is, in fact, the result of a specific regulatory framework that creates the extreme inequality that people often view as a given. In order to deal with the coronavirus, the state intervenes differently, then, but not necessarily to a greater extent.

With Foucault in mind, one would say: What happens is not exceptional but expectable; we see contemporary repetitions and syntheses of old biopolitical forms, such as discipline, individualization of responsibility, security technologies based on statistical and medical knowledge. Philipp Sarasin (2020) reminds us that there is no singular concept of biopolitics in Foucault's work, but rather that Foucault offers a careful differentiation of distinct modes of power employed as responses to an epidemic, all of which are used during the coronavirus crisis. That nothing has changed fundamenttally is affirmed by other sociological analysts: Andreas Reckwitz (2020) describes the situation as typical risk politics and Armin Nassehi (2020), following a more system-theoretic idiom, points to the fact that all functional systems, such as law, politics, and economy, play their routine roles. So we are witnessing a state of exception rather in a directly phenomenal sense, as one experiences it as an exception; yet very little has changed fundamentally, in terms of social and political systems, discourses, or power mechanisms.

Arguing that the situation is not fundamentally exceptional entails, furthermore, that our experiences of exceptionality in our concrete lives are highly differentiated according to our social position. That nothing has changed fundamentally means that the lives of many vulnerable people changed dramatically for the worse, while well-off people manage relatively well in the pandemic. The current situation may be understood, then, as the non-exceptional continuation of the exploitation mechanisms of biopolitical capitalism on the one hand, and heteronormativity on the other, as heteronormative lockdown measures hit queer people particularly hard. The contact restrictions were tailored to heteronormative lifestyles in many countries without taking queer forms of sociality into account (Trott, 2020).

Macro-economically, the same combination of phenomenal exception and structural continuity is evident: While the Covid situation seems to lead governments to overcome the anti-Keynesian antideficit spending mode of neoliberal austerity by enormous financial aid programs both in Europe and in the U.S., neoliberal financialization continues to grow (Šumonja, 2021). The discrepancy between rich and poor has been further boosted while stock markets skyrocketed (Gebeloff, 2021). However, governments do not make any earnest attempts to finance the corona-deficit by redistributing wealth, for example through significant wealth taxation of the richest 10 percent. If no broader 
redistribution scheme is put into place, there will be a fallback to severe austerity measures that will prevent public investments and further dismantle the welfare state. Alongside injustice and further exploitation that such austerity brings, it is also likely to strengthen heteronormative and traditionnalist family politics as a functional alternative to welfare organized reproduction. Furthermore, lockdown procedures often privilege the economy: in the case of Germany, for example, hardly any regulation has been introduced for workplaces, while the private sphere, the cultural sector, and the food service sector are severely regulated and restricted. Not only does this cause psychological burdens, but it may also lead to the destruction of urban infrastructures, such as bars and nightclubs. Together with austerity measures that might force people from these sectors to work in other domains, these developments severely endanger queer cultural and subcultural spaces.

\section{Democratic and Populist Biopolitics 2}

The urgent question is, then, what options we have, and what follows from biopolitical theory, except for this dispiriting analysis of the perpetuation of power structures. Along with other scholars, I suggest introducing a normative term, "democratic biopolitics," in order to critically evaluate the politics of COVID-19. Of course, this does not provide concrete steps to be taken, but rather a theoretical contribution to normativity in biopolitical theory, and it offers a reflection of the role of the state and civil society in the pandemic. In contrast to the widespread understanding of the term, I do not view democratic biopolitics as contradictory to the state but show that they are a matter of pluralist deliberation and state power.

Traditional analyses of biopolitics focus on state and medical institutions and how they govern the behavior of individuals and societies. These analyses carve out the (potentially) repressive effects of such biopower on individuals and communities and focus on the long-term development of discourses, technologies of power, and modes of subjectification. Such biopolitical analyses are structured "top-down" and have no conceptual place for agency, freedom, and democratic decision-making. This focus of biopolitical theory on state institutions and repressive power is, however, only a sideeffect of Foucault's central contribution to critical social analysis, namely, to show that repressive power works within subjects, as they are constituted by power in the process of subjectification. Arguably, this framework of subjectification refrains from clarifying how agency, freedom, resistance, and emancipation can be conceptualized - as a result, this apparent lack of clarity is one of the most widely discussed questions in Foucault scholarship (Lemke, 2019; Schubert, 2020b).

In order to counterbalance the focus on repressive power within biopolitical theory, recent years have seen attempts to conceptualize "democratic biopolitics" (Prozorov, 2019) which accounts for the agency of citizens and activists, and their active participation in biopolitics. This usage of democratic biopolitics is both analytical - following Foucault's insight that since power comes from below, it is necessary to take into account the manifold participants in biopolitical processes - and normative:

\footnotetext{
2 Parts of this section have been previously published in Schubert 2020a.
} 
participation, that is political and ethical deliberation of biopolitical developments, is something to be valued and supported. I have developed such a concept of democratic biopolitics in my discussion of HIV-Pre-Exposition-Prophylaxis (PrEP) and I have shown that PrEP is not (only) a strategy of big pharma to make money, but actively desired by and developed with the gay community (Schubert, 2019). PrEP is part of an ethical re-negotiation of sex in the gay community and can help to destigmatize sex and fight homonormativity. The democratic biopolitics of PrEP include activists' work to demand that PrEP is covered by public healthcare systems, which was successfully completed in Western Europe in 2019, with Spain and Germany as the last countries to join (Schubert, 2021). In Central and Eastern Europe, access to PrEP is still a matter of economic privilege as it is not covered by public insurances. Because of the complex involvement of the affected community and the emancipatory effect this biotechnology has on gay lives, PrEP provides an ideal case study for the concept of democratic biopolitics.

Regarding COVID-19, a discussion of the potential of democratic biopolitics quickly emerged, especially in reaction to Agamben's (2020) interpretation of coronavirus politics as complete repression. Along similar lines to my analysis of the ethical deliberations of sexual practices in the gay community, Sotiris (2020) imagines collective care in a non-coercive way in which practices like social distancing are deliberated democratically, thus not only based on "the authority of experts" but on a "democratization of knowledges." Sotiris gives HIV politics and the knowledge production of ACTUP as an example of such democratization of knowledge.

However, such an analysis of democratic biopolitics fails to grasp what is remarkable about the coronavirus situation. For the first time, biopolitical considerations became a leading issue in political debates. Due to homophobia, HIV was not a concern of mainstream politics for a long time, but othered - and this is fundamentally different in the case of COVID-19 (Schubert, 2021) ${ }^{3}$. That biopolitics entered mainstream political deliberation, rather than community-based coping strategies, should be interpreted as the democratic aspect of coronavirus politics. It goes along with a shift in the temporality under focus in the biopolitical analysis: while it traditionally focuses on tracing the historical genealogy of the development of power and knowledge, in this case, the analysis of biopolitics as differentiated vulnerability in capitalism focuses on the present. While framed by such biopolitical power structures, democratic biopolitics is a matter of deciding between present alternatives. This possibility to politically select between alternatives is a key aspect of the democratic biopolitics of COVID-19. And such democratic biopolitics are a matter of state power. This is a clear difference from Sotiris' use of the term "democratic biopolitics," which positions democratic biopolitics in contrast to state power.

\footnotetext{
${ }^{3}$ See Schaffar (2020) for a more nuanced comparison of HIV and COVID biopolitics, which nevertheless shares the focus on solidarity in communities rather than on a state level that I deem insufficient for analyzing the democratic biopolitics of COVID-19.
} 
To define the concept of democratic biopolitics more precisely, and to clarify that democratic biopolitics cannot be described through the binary between community ethics and the state, I suggested a contrasting term (Schubert, 2020a): populist biopolitics, a form of decay of democratic biopolitics, which points to the danger that can arise from the unmediated and grassroots-based norm-setting that Sotiris understood by the term democratic biopolitics.

Both concepts - traditional biopolitics focusing on the repressive state, and democratic biopolitics focusing on the emancipatory agency of activists and the community - fail to account for a new form of biopolitical normalization and repression that occurs in the pandemic and that should be termed "populist biopolitics." Just as populism is a degeneration of democracy, populist biopolitics is a degeneration of democratic biopolitics. It is a repressive and paternalistic form of democratic biopolitics, i.e. when members of the community and not the state engage in biopolitics that limits freedom and normalizes others. Populist biopolitics occurs both online and offline when members of the community shame each other for supposedly irrational and non-solidary behavior, such as, for example, leaving the house or meeting with friends, encapsulated in \#staythefuckathome. Populist biopolitics also occurs in more formal political discourse, when the state is pressured to enact stricter regulations on the population.

The populist biopolitics of the coronavirus allows us to sharpen the recent concept of democratic biopolitics when put into relation with the notions of populism and democracy as discussed in political theory. Following Müller (2016), populists claim to represent the true interests of the people by monopolizing moral truth and thus rejecting pluralism. Populist biopolitics in times of the coronavirus shares these elements: We are called to do the only morally correct thing in order to protect other people, while alternative political considerations, such as the differentiated vulnerabilities outlined above, are excluded from deliberation. This framing does not allow for pluralist deliberation, but rather assumes the role of speaking the moral and political truth in the name of the people.

Populist biopolitics may also occur in an opposite form: the denial of the pandemic and the rejection of all social distancing and lockdown measures. Such anti-coronavirus movements formed quickly in Germany, bringing together a wide spectrum of conspiracy theorists and right-wing populists, fueled by widespread esoteric beliefs (Oltermann, 2021). Here, the universal morality in the name of the "real people" is not directed towards protection from the coronavirus itself, but from the restrictions against the coronavirus. Such populist biopolitics are framed as a defense of democracy that is, according to this position, threatened by coronavirus regulations.

I call both of these opposite extremes "populist biopolitics" because they both take one biopolitical solution as absolute, negating the differentiated vulnerability that has always been the core of capitalist biopolitics. I want to be very clear that pointing out this formal similarity is not meant as equating these two political extremes. I am well aware that restrictive coronavirus politics with the 
aim of protecting vulnerable members of society is a rather leftist agenda, while coronavirus denial is fueled by right-wing conspiracy theories, and relatively lax measures are demanded mostly by people with economic interests.

Calling both extremes "populist biopolitics" helps to further define democratic biopolitics: as biopolitics is politics of differentiated vulnerability, democratic biopolitics entail the democratic negotiation and deliberation of these differentiated vulnerabilities. Differentiated vulnerabilities stem from the multiplicity of different social positions and their respective patterns of vulnerability. Such social multiplicity entails a wide range of interests, identities, and values. Thus, democratic biopolitics relies on a pluralist understanding of the political, in contrast to the absolutist populist biopolitics, which imagines a unified, coherent, and real interest of the people. Now, such negotiation of differentiated vulnerabilities is already taking place in coronavirus politics. For example, COVID-19-related class discrepancies between working-class people who keep the supply chains running, and the home office class, the unequal distribution of care work between men and women, or the different impact of lockdown measures on rich people who own spacious houses and poor people who rent tiny flats were widely debated in mainstream media. That differentiated vulnerability is an explicit part of public debates on coronavirus politics is already remarkable since the differentiated vulnerabilities that form part of biopolitics were rarely debated in mainstream media outlets, but usually take place within the bubbles of critical theoretical debates.

Democracy, in contrast to populism, is essentially pluralist ${ }^{4}$. This pluralism must be ensured by constitutional law and by a lively public debate, that includes a wide plurality of voices - politicians, epidemiologists and other experts; for example, social scientists, and members of civil society, among others. Democratic politics need to weigh different policy aims, such as preventing the collapse of the health care system while reducing the impact on the economy, and it needs to make decisions that lead to differentiated vulnerabilities.

The concept of democratic biopolitics is also normative and critical: While it is true that democratic biopolitics are at play during the coronavirus crisis, these politics, as shown, lead to a continuation and reinforcement of existing structures of inequality. In order to render these biopolitics more democratic, inequality must be criticized and equality demanded. Democratic biopolitics understood normatively, consists of the critical analysis of differentiated vulnerabilities with the aim of easing the inequalities through political measures. The key would be to avoid regulations that reinforce existing structures of discrimination, as often happened during the coronavirus pandemic. For example, making exceptions from otherwise strict limitations of social contacts only for those who live in classical, hetero- and homonormative relationships, as was done during Christmas 2020 in Germany,

\footnotetext{
${ }^{4}$ I follow such a liberal definition of democracy in contrast to populism because this can capture the difference between absolutist (populist) and pluralist (democratic) biopolitics. This does not rule out the possibility of a leftist populism that is compatible with pluralism and democracy because it does not rely on a given notion of "the good of the people," but constantly and pluralistically re-constitutes this notion through social critique (Kempf, 2020).
} 
reinforces heteronormativity and ignores the differentiated vulnerability of queer persons. Such politics can take a direct populist form, as in the claim that the general interest is to privilege straight lifestyles and that queers need to restrict themselves in the name of the greater good of the people. A critical analysis of the differentiated vulnerabilities is also required regarding the regulations of the economic sphere, which tend to put workers at risk in order to ensure profits, for example through insufficient safety measures (Cauwer and Christiaens, 2020), while systematically destroying social reproduction through very strict regulations of the private sphere. The distribution of the burdens of restrictions among social groups and social systems is a matter of biopolitical power and representation, and it is by no means without alternatives that more severe restrictions are enforced on the private sphere rather than on the economy.

Specific guidelines for what should be done and which regulations should be put in place cannot of course offered in a theoretical text. However, the biopolitical theory demonstrates the extent to which capitalism and biopolitics are intrinsically connected, and that biopolitics is a matter of differentiated vulnerabilities. That the related inequalities and discriminations are reinforced during the coronavirus pandemic is primarily a matter of structural biases in the political representation, that privileges the interests of the rich, straight, upper-class. Democratization means first and foremost better access to and representation of weaker voices that are not taken into account in democratic deliberations. This would lead to the redistribution of wealth and the realignment of the relations between restrictions in the economic and private sphere.

\section{Works Cited}

Agamben, Giorgio, Foucault, Michel, Nancy, Jean-Luc, Esposito, Roberto, Benvenuto, Sergio, Dwivedi, Dipankar, et al. (2020), "Coronavirus and philosophers", European Journal of Psychoanalysis, http://www.journal-psychoanalysis.eu/coronavirus-and-philosophers/

Cauwer, Stijn De and Tim Christiaens (2020), "The Multitude Divided: Biopolitical Production During the Coronavirus Pandemic", A RETHINKING MARXISM Dossier: Pandemic and the Crisis of Capitalism: 118-127.

Dean, Mitchell (1999), Governmentality: Power and Rule in Modern Society, London, SAGE Publ.

Deleuze, Gilles (1992), "Postscript on the Societies of Control", October 59: 3-7, http://www.jstor.org/stable/778828

Federici, Silvia Beatriz (ed.) (2014), Caliban and the Witch, 2, New York, NY, Autonomedia.

Foucault, Michel ([1975] 1977), Discipline and Punish: The Birth of the Prison. With the assistance of A. Sheridan, London, New York, Penguin Books.

Foucault, Michel (1978), The History of Sexuality, Vol. I, An Introduction, New York, Pantheon Books.

Foucault, Michel (2003), Society Must Be Defended: Lectures at the collège de France 1975-76, New York, Picador.

Foucault, Michel (2007), Security, Territory, Population: Lectures at the Collège De France, 1977-78, Michel Senellart (ed.), Basingstoke, Palgrave Macmillan. 
Foucault, Michel (2010), The Birth of Biopolitics: Lectures at the Collège De France, 1978 -79, Michel Senellart (ed.), Basingstoke, Palgrave Macmillan.

Gebeloff, Robert (2021), "Who Owns Stocks? Explaining the Rise in Inequality During the Pandemic", 26 January, The New York Times, https://www.nytimes.com/2021/01/26/upshot/stocks-pandemic-inequality.html

Harvey, David (2004), "The New Imperialism: Accumulation by Dispossession", Socialist Register, 40: 63-87.

Kempf, Victor (2020), "Is there another people? Populism, radical democracy and immanent critique", Philosophy \& Social Criticism, 80.1. http://doi.org/10.1177/0191453720910450.

Lemke, Thomas (2019), Foucault's Analysis of Modern Governmentality: A Critique of Political Reason, English-language edition, London, Brooklyn, NY, Verso.

Lorenzini, Daniele (2021), "Biopolitics in the Time of Coronavirus", Critical Inquiry, 47.2: 40-45. https://doi.org/10.1086/711432

Marx, Karl (1991), Das Kapital: Kritik der politischen Ökonomie. Erster Band, Hamburg 1890. With the assistance of R. Nietzold, W. Focke and H. Skambraks. Gesamtausgabe Abteilung 2 Band 10,Berlin, Dietz Verlag. https://doi.org/10.1515/9783050076577

Nassehi, Armin (2020), "Corona-Maßnahmen: Das Virus Ändert Alles, Aber Es Ändert Sich Nichts", 4 May, Die Zeit 056Z, https://www.zeit.de/kultur/2020-05/corona-massnahmen-lockerungenkontaktverbot-lockdown-social-distancing

Oltermann, Philip (2021), "Ginger Root and Meteorite Dust: The Steiner 'Covid Cures' Offered in Germany", 10 January, The Guardian, https://www.theguardian.com/world/2021/jan/10/gingerroot-and-meteorite-dust-the-steiner-covid-cures-offered-in-germany

Preciado, Beatriz (2013), Testo Junkie: Sex, Drugs, and Biopolitics in the Pharmacopornographic Era, New York, The Feminist Press at CUNY.

Prozorov, Sergej (2019), Democratic Biopolitics: Popular Sovereignty and the Power of Life, Edinburgh, Edinburgh University Press. https://doi.org/10.3366/edinburgh/9781474449342.001.0001

Reckwitz, Andreas (2020), "Risikopolitik", Die Corona-Gesellschaft, Michael Volkmer and Karin Werner (eds.), Bielefeld, transcript Verlag: 241-252. https://doi.org/10.14361/9783839454329024

Robinson, Cedric J (2000), Black Marxism: The Making of the Black Radical Tradition, Chapel Hill, North Carolina, University of North Carolina Press, http://site.ebrary.com/lib/academiccompletetitles/home.action

Rose, Nikolas S. (2007), The Politics of Life Itself: Biomedicine, Power, and Subjectivity in the TwentyFirst Century, Information series, Princeton, New Jersey, Princeton Univ. Press. https://doi.org/10.1515/9781400827503

Sarasin, Philipp (2020), "Mit Foucault Die Pandemie Verstehen? - Geschichte Der Gegenwart", Geschichte der Gegenwart, https://geschichtedergegenwart.ch/mit-foucault-die-pandemieverstehen/

Schaffar, Wolfram (2020),"Solidarische Biopolitik: Kondome, Masken Und Die Parallelen Zwischen HIV- Und Corona-Pandemie", Zeitschrift Luxemburg, https://www.zeitschrift- 
luxemburg.de/solidarische-biopolitik-kondome-masken-und-die-parallelen-zwischen-hiv-undcorona-pandemie/

Schubert, Karsten (2019), "The Democratic Biopolitics of PrEP", Biopolitiken - Regierungen Des Lebens Heute, Kathrin Braun and Helene Gerhards (eds.), Wiesbaden, Springer Fachmedien Wiesbaden: 121-53. https://doi.org/10.1007/978-3-658-25769-9_5

_- (2020), "Die Krux Mit Der Kernfamilie", Philosophie Magazin, https://www.philomag.de/artikel/die-krux-mit-der-kernfamilie

Schubert, Karsten (2020a), "Crying for Repression: Populist and Democratic Biopolitics in Times of COVID-19", Critical Legal Thinking, https://criticallegalthinking.com/2020/04/01/crying-forrepression-populist-and-democratic-biopolitics-in-times-of-covid-19/

(2020b), "Freedom as Critique: Foucault Beyond Anarchism", Philosophy \& Social Criticism, 47.5: 634-660. https://doi.org/10.1177/0191453720917733

(2021), "A New Era of Queer Politics? PrEP, Foucauldian Sexual Liberation, and the Overcoming of Homonormativity", https://papers.ssrn.com/sol3/papers.cfm?abstract_id=3901719

Sotiris, Panagiotis (2020), "Against Agamben: Is a Democratic Biopolitics Possible?", Critical Legal Thinking, https://criticallegalthinking.com/2020/03/14/against-agamben-is-a-democraticbiopolitics-possible/

Šumonja, Miloš (2021), "Neoliberalism Is Not Dead - on Political Implications of Covid-19", Capital \& Class, 45.2: 215-227. https://doi.org/10.1177/0309816820982381

Trott, Ben (2020), "Queer Berlin and the Covid-19 Crisis: A Politics of Contact and Ethics of Care", Interface: A journal for and about social movements, 12.1: 88-108. 